doso en la 1

ar ejemplos a

is funcionalidac uso, dependiende encarnan los conceptos detr por e $\Lambda$ influ
$\mathrm{Pe}$ infin:

Las formas $d r$ oceso de sig ialidad .

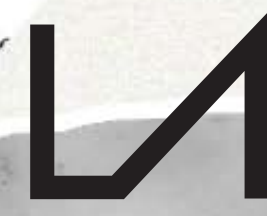

R E V I S A
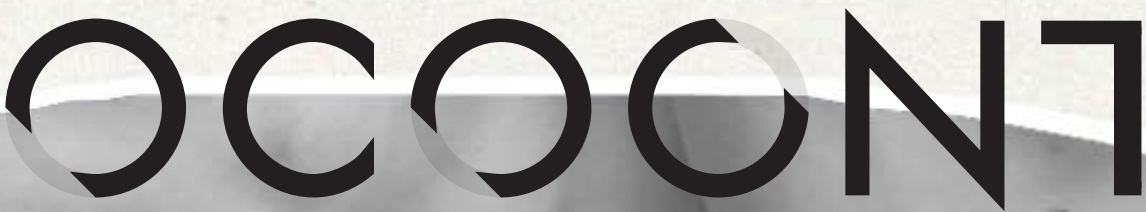

D $E$

No $6 \cdot 2019 \cdot$ ISSN 2386-8449

"El producto del diseñador es un proyecto, el estado previo de un objeto", Entrevista con Norberto Chaves, por Fernando Infante

El papel de la investigación y la teoría en diseño. Una conversación abierta, por Fernando Infante y María Jesús Godoy

UT PICTURA POESIS

Abandonar la escritura. Poesía experimental y manifiesta, Ignacio Gómez de Liaño

PANORAMA: FILOSOFÍA DEL DISEÑO Sección coordinada por Fernando Infante y María Jesús Godoy

Pensar el diseño, Fernando Infante y María Jesús Godoy (Coordinadores)

TEXTOS INVITADOS

Estatus y estado del điseño más allá del objeto, Pedro Medina Reinón

Mar de Nubes, Cuerpo de Cristal, Dionisio González

ARTÍCULOS

Understanding Design Aesthetics beyond Functional Beauty accounts, Lucía Jiménez Sánchez

Estética y diseño industrial: debates y controversias, Joan M. Marín

Del ornamento al delito. El diseño y la sociedad en Charles Baudelaire y Adolf Loos, Jorge López Lloret

When is Architecture not Design? Saul Fisher

Diseño y habitabilidad: una aproximación basada en los lenguajes de patrones, Antonio Hidalgo Pérez

Marcel Breuer: un diseñador global. Experiencias en el ámbito de la vivienda prefabricada, Salvador J. Sanchis, Ignacio Peris y Pedro Ponce Diseño y artes escénicas: el papel de Oskar Schlemmer en Das Triadische Ballett y la actualidad de la Bauhaus, Milagros García Vázquez Lo performativo en prácticas de arte y diseño actuales vinculadas a procesos de innovación social. El caso de La Venezia che non si vede y de La borda, Tània Costa Gomez

Articulaciones de la estética y el diseño. El caso de la evaluación a partir de la investigación dirigida en la carrera de diseño escénico de la Universidad de las Artes de Cuba, Mara Rodríguez Venegas y Xiomara Romero Rojas

SUPLEMENTO

El diseño, la ciudad y un lápiz de labios, Mercedes Espiau, Mar García Ranedo y Alejandro Rojas mas. 


\section{UつCつCNTE}

No $6 \cdot 2019 \cdot \operatorname{ISSN} 2386-8449 \cdot$ DOI 10.7203/LAOCOONTE.5.15381

https://ojs.uv.es/index.php/LAOCOONTE/index

COORDINACIÓN EDITORIAL

Anacleto Ferrer (Universitat de València)

Francesc Jesús Hernàndez i Dobon (Universitat de València)

Fernando Infante del Rosal (Universidad de Sevilla)

SECRETARÍA DE REDACCIÓN

Lurdes Valls Crespo (Universitat de València)

Vanessa Vidal Mayor (Universitat de València)

COMITÉ DE REDACCIÓN

Tamara Djermanović (Universitat Pompeu Fabra), Rosa Fernández Gómez (Universidad de Málaga), Anacleto Ferrer (Universitat de València), Ilia Galán (Universidad Carlos III), Ana María García Varas (Universidad de Zaragoza), María Jesús Godoy (Universidad de Sevilla), Fernando Infante del Rosal (Universidad de Sevilla), Miguel Ángel Rivero (Universidad de Sevilla), Miguel Salmerón (Universidad Autónoma de Madrid), Gerard Vilar (Universitat Autònoma de Barcelona).

COMITÉ CIENTÍFICO INTERNACIONAL

Rafael Argullol* (Universitat Pompeu Fabra), Luis Camnitzer (State University of New York), José Bragança de Miranda (Universidade Nova de Lisboa), Bruno Corà (Università di Cassino), Román de la Calle* (Universitat de València), Eberhard Geisler (Johannes Gutenberg-Universität Mainz), José Jiménez* (Universidad Autónoma de Madrid), Jacinto Lageira (Université Paris 1 Panthéon-Sorbonne), Bernard Marcadé (École Nationale Supérieure d'Arts de Paris-Cergy), Elena Oliveras (Universidad de Buenos Aires y Universidad del Salvador), Pablo Oyarzun (Universidad de Chile), Francisca Pérez Carreño* (Universidad de Murcia), Bernardo Pinto de Almeida (Faculdade de Belas Artes da Universidade do Porto), Luigi Russo (Università di Palermo), Georges Sebbag (Doctor en Filosofía e historiador del surrealismo), Zoltán Somhegyi (University of Sharjah, United Arab Emirates), Robert Wilkinson (Open University-Scotland), Martín Zubiria (Universidad Nacional de Cuyo). *Miembros de la Sociedad Española de Estética y Teoría de las Artes, SEyTA

\begin{tabular}{lll}
\hline DIRECCIÓN DE ARTE & REVISIÓN DE TEXTOS & TRANSCRIPCIÓN DE TEXTOS \\
El golpe. Cultura del entorno & Antonio Cuesta & Álvaro G. Serna
\end{tabular}

(cc) BY Excepto que se establezca de otra forma, el contenido de esta revista cuenta con una licencia Creative Commons Atribución 3.0 España, que puede consultarse en http://creativecommons.org/licenses/by/3.0/es/deed.es

EDITA

\section{SEyTA.}

CON LA COLABORACIÓN DE

\begin{tabular}{|c|c|c|c|}
\hline $\begin{array}{l}\text { VNIVERSITAT } \\
\text { B VALENCIA } \\
\text { Institut te Creativitat } \\
\text { | |nnovacions Educatives }\end{array}$ & $\begin{array}{l}\text { VNIVERSITAT } \\
\text { IE ÖVALENCIA Departament de Filosofia }\end{array}$ & 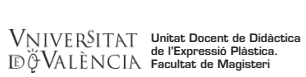 & \\
\hline $\begin{array}{l}\text { DEPARTAMENTO DE ESTÉTICA } \\
\text { E HISTORIA DE LA FLLOSOFIA }\end{array}$ & $\frac{\text { UAW }}{\frac{\text { UNIVRSSIDAD AUTONOMA }}{\text { DE MADRID }}}$ & $\begin{array}{l}\text { Universitat Autònoma } \\
\text { de Barcelona }\end{array}$ & $\begin{array}{l}\text { VNiVERSiDAD } \\
\text { Departamento de Filosofia, Lógica y Estética }\end{array}$ \\
\hline
\end{tabular}

LAOCOONTE aparece en los catálogos: 


\section{LつCつCN7E}

"Cuanto más penetramos en una obra de arte más pensamientos suscita ella en nosotros, y cuantos más pensamientos suscite tanto más debemos creer que estamos penetrando en ella".

G. E. Lessing, Laocoonte o los límites entre la pintura y la poesía, 1766.

Vo hay cól.

létodo, de pen.

:ión en general. Ith

zar la forma para el $\mathrm{n}$.

eptual por las orígenes

la, el objeto, la exposición

storia, porque existe en el $\mathrm{m}$

das sus raíces. Desde alli cc _. panoram

n conceptual y donde el émencia del con 'iseñado, como es el a al objeto y el di $\begin{array}{ll}\text { igen } \mathrm{de}^{\text {to }} \text { la inmer } & \text { tolvidada, o comc } \\ \text { trozo de madera ar }\end{array}$ a manera dorm comunicar ene nundo. Seguin? sngo en manos te el método $C$ les. A partir c teria prima $\mathrm{p}_{\mathbf{c}}$

'xto se puede:

¿ño, en proyea

amientos de $\mathrm{u}$

a conscie-

.)

en la publicación jue "plos de la impor te las nalidades porqu ura un ${ }^{2}$ diendo de qui zenerar $\mathrm{u}$ ción de nr? lne

in-

n-

is.

le http:,

le crear visualidades. A partir de.

ellas la propia materia prima para un en que desde un texto se puede generar $u_{11}$ i

Pensar en diseño, en proyección de nue

posibles comportamientos de una colecti

presente como una consciencia del hecho que estamos elaborando, significac

nuestro entorno (..)

Cardoso, R. C. Rafael. (2014). Design para um mundo complexo. Sãc asil: Cosac Naify. 


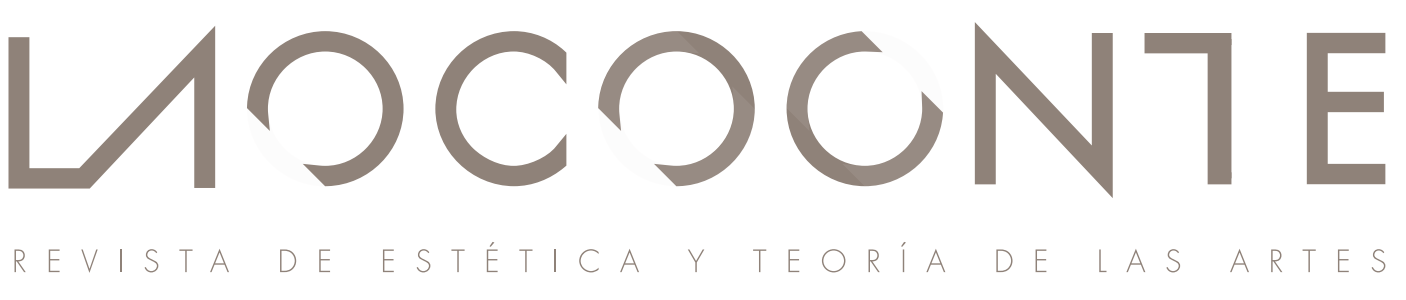

$\mathrm{N}^{\circ} 6 \cdot 2019$

PRESENTACIÓN

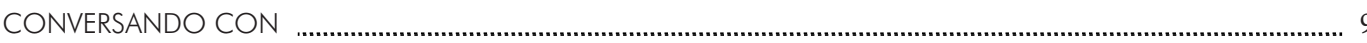

"El producto del diseñador es un proyecto, el estado previo de un objeto", Entrevista con Norberto Chaves,

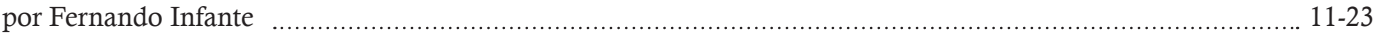

El papel de la investigación y la teoría en diseño. Una conversación abierta, por Fernando Infante

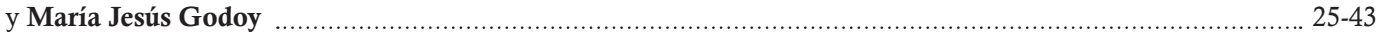

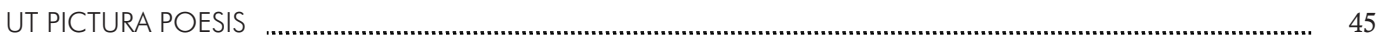

Abandonar la escritura. Poesía experimental y manifiesta, Ignacio Gómez de Liaño ................................................ 47-95

Imágenes de Laocoonte n. 6, de Isadora Gonzaga ................................................................................................... 96-97

PANORAMA

FILOSOFÍA DEL DISEÑO

Pensar el diseño, Fernando Infante y María Jesús Godoy (Coordinadores) .............................................. 101-105

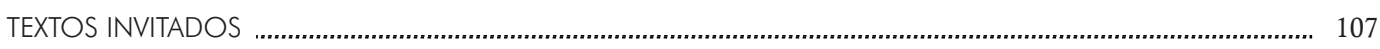

Estatus y estado del diseño más allá del objeto, Pedro Medina Reinón . ................................................... 109-125

Mar de Nubes. Cuerpo de Cristal, Dionisio González .............................................................................. 127-133

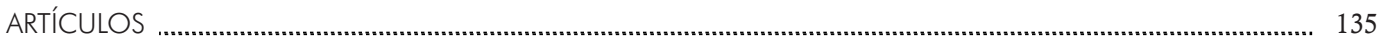

Understanding Design Aesthetics beyond Functional Beauty accounts, Lucía Jiménez Sánchez ................. 137-149

Estética y diseño industrial: debates y controversias, Joan M. Marín _...................................................... 150-164

Del ornamento al delito. El diseño y la sociedad en Charles Baudelaire y Adolf Loos, Jorge López Lloret ... $165-182$

When is Architecture not Design? Saul Fisher ……............................................................................. 183-198

Diseño y habitabilidad: una aproximación basada en los lenguajes de patrones, Antonio Hidalgo Pérez ...... 199-215

Marcel Breuer: un diseñador global. Experiencias en el ámbito de la vivienda prefabricada,

Salvador José Sanchis, Ignacio Peris y Pedro Ponce

Diseño y artes escénicas: el papel de Oskar Schlemmer en Das Triadische Ballett y la actualidad de la Bauhaus, Milagros García Vázquez

Lo performativo en prácticas de arte y diseño actuales vinculadas a procesos de innovación social.

El caso de La Venezia che non si vede y de La borda, Tània Costa Gomez

Articulaciones de la estética y el diseño. El caso de la evaluación a partir de la investigación dirigida en la carrera de diseño escénico de la Universidad de las Artes de Cuba, Mara Rodríguez Venegas

y Xiomara Romero Rojas

SUPLEMENTO 
Walter Gropius. La vida del fundador de la Bauhaus, Jorge Martínez Alcaide

¿Qué significa pensar la política desde la estética? Àger Pérez Casanovas

Ideologías estéticas en los orígenes de la pintura moderna, José Luis Plaza Chillón 300-303

Sobre a estética, Luis Carlos Pereira

Músicas populares. Sociedad y territorio: Sinergias entre investigación y docencia, Mar Aleixandre Badenes.

307-309

La necesidad de la mirada antropológica sobre la literatura, Pablo de Benito David

A propósito de Chandler, o la novela policíaca como tratado filosófico, Juan Evaristo Valls Boix

Videre aude!, Anacleto Ferrer

La inaplazable memoria del dolor y el sufrimiento, Antonio Notario Ruiz

La alargada sombra de la pintura, Raquel Baixauli

Sondear la maravilla, Juan Evaristo Valls Boix

... Y lo sabes, Marc Hernández Montoro

Arqueologías de la modernidad en las artes. Ensayo estético, Carlota Fernández-Jáuregui Rojas

Estética de la Instalación, Luis Cemillán Casis

La Herencia de otra época, María Jesús Godoy Domínguez

Del Theatrum Mundi al Gran Vidrio, Miguel Salmerón Infante

Imágenes de Isadora Gonzaga.

Fotografía de portada de Tamara Djermanovic intervenida por Isadora Gonzaga.

Los coordinadores de la sección Panorama: Filosofia del diseño agradecen

a Antonio Molina Flores su colaboración. 
ner.

llobj vidada, o de ma la publica. los de la im nalidades po ndientn $\mathrm{A}$ -
, la

que e.

usdño, si nn

ज. " da yara el mu tual y d

or enc or las orígenes un tmo, fía del diseño,

rpintero que'curra la forma de

eña Desige para un mundo complexo, de los bienes producidos por el hombre :tores subjetivos también influyen en su

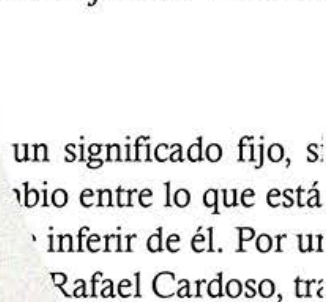

Rafael Cardoso, tri

No hay cómo no e método, de pensa 1, donde la reación en geperal. salizar la forma pa. rue amb ${ }_{\text {Snceptual por }}{ }^{1}$

$$
\text { -rola ol } n^{\prime}
$$

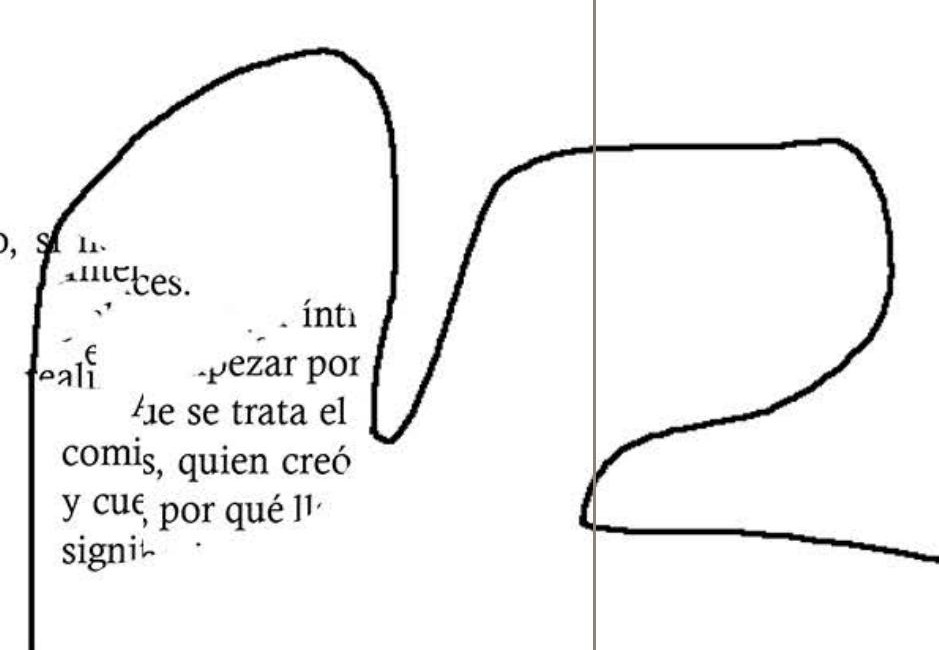

LOCOCNTE

PANORAMA: FILOSOFÍA DEL DISEÑO

Fernando Infante del Rosal y María Jesús Godoy Domínguez

(Coordinadores) 
No hay cómo no hablar de una filosofía del diseño, si no de izar la forma para el mundo sensible. Tción de formas y de la

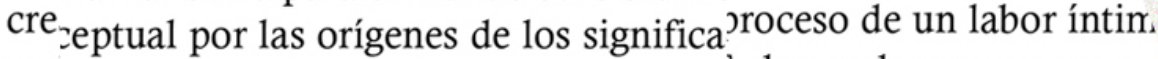

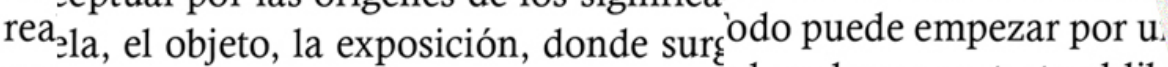

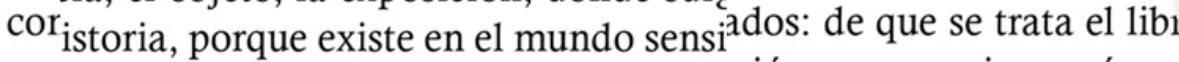
noładas sus raíces. Desde allí cojo el hilo gió, que es, quien creó y p su len conceptual y donde el está ubicado.ible o aún, por qué llama as

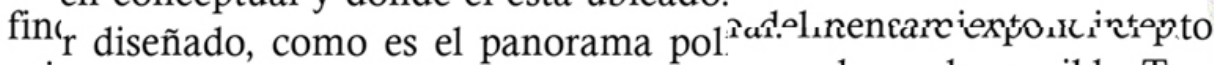
ori $_{\text {evolando la inmanencia del concepto. }}$ para el mundo sensible. Tc ce a s a forma al objeto y el diseñad ${ }^{\text {as }}$ orígenes de los significa)olo sob lengua olvidada, o como un cr la exposición, donde surg̨ido - nrocesr a un trozn de madera amnrfo le existe en el mundo sensin trai lengua olvidada,adas sus raíces. Desde allí cojo el hilona de ablo de procesc a un trozo de men conceptual y donde el está ubicado. perspectiva de lidoso en la publr diseñado, como es el panorama polndo ho, un camino diar ejemplos de levolando la inmanencia del concepto.: por una investigacióus funcionalidadı a forma al objeto y el diseñadı infl ro, el cuento, luso, dependiendı lengua olvidada, o como un $\mathrm{C} i^{\prime}$

qué, cuál e s nrecese a un trozo de madera amorfo

ata el 1

،en creó y pu.

or qué llama así, d

miento y intento a lles
- puede inferir de él. Por un in -reación ". (Rafael Cardoso, trad. 26 el ambiente que cerca el ol, especie de un danza en que ambos eleme iles son los símbolos que estso.

lmente, el contenido contextrño y hacer diseño, es antes de todo cue rna el papel de un tra o que toma la forma $\mathrm{d}^{\text {g }}$ gradual, donde la idea $\mathrm{do}_{\text {, las ideas, los relacioname }}$ danza en que ambos ropio proceso y también de r

'esign para un mundo liseñar, me planteé la cuesti' s bienes producidos por seño, es antes de tod prima eso me dá? Ejemp' es subjetivos también inf ble. Diseñar puede se ese texto, construyo el d

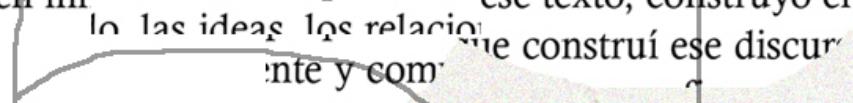

1 un significado fijo, sino que expresajue ${ }^{\dagger}$ mbio entre lo que está incrustado en Sre ¿de inferir de él. Por un lado, las form ". (Rafael Cardoso, trad. 2014)

rradual, donde la i’ 
- ormas y de rapo.

eso de un labor íntimo, un udo puede empezar por una inves 'dos: de que se trata el libro, el cu jió, que es, quien creó y por qué, ble o aún, por qué llama así, donı del pensamiento y intento a lle: Cual es el ambiente que cerca e ico. cuáles son los símholos aı

de una filosofía del diseño, si r e construcción de formas y de exponer el proceso de un labor í o sensible. Todo puede empezar los significados: de que se trata h, donde surgió, que es, quien creó y po mundo sensible o aún, por qué llama as cojo el hilo del pensamiento y intentc está ubicado. Cual es el ambiente que $\mathrm{g}$ anorama político, cuáles son los símb el concepto. Gradualmente, el conten y el diseñador encarna el papel de ur como un carpintero que toma la forr
LAU1 L11 glilla1. 111 n un sigizar la forma para e] ede inferifeptual por las orígt “. (Rafabla, el objeto, la exp istoria, porque exist y gradua adas sus raíces. De: en conceptual y do sible. $D$ : $r$ diseñado, como do, las icevolando la inman propio pri diseñar, a forma al prima e lengua olvi ese textos nrncesr a un trnzo ue construí ese discurso, he hecho de ara un reconfiguración de significado en para ilustrar... (en construccion) antiguas formas, es lanzar al mundo 1. La responsabilidad aquí se hace tamos elaborando, significados para

am mundo complexo. São Paulo,

1 agosto). Significado. Recuperado 1 br/significado/

\section{ИつCつCN7E}

PANORAMA: FILOSOFÍA DEL DISEÑO ARTÍCULOS 
- ormas y de rapon

aso de un labor íntimo, un udo puede empezar por una inves 'dos: de que se trata el libro, el cu rió, que es, quien creó y por qué, ble o aún, por qué llama así, donı del pensamiento $\mathrm{y}$ intento a lle Cual es el ambiente que cerca e ticn. cuáles son los símbolos a

de una filosofía del diseño, si r e construcción de formas y d $\epsilon$ exponer el proceso de un labor í o sensible. Todo puede empezar. los significados: de que se trata 1, donde surgió, que es, quien creó y po mundo sensible o aún, por qué llama as cojo el hilo del pensamiento y intento está ubicado. Cual es el ambiente que $q$ anorama político, cuáles son los símb lel concepto. Gradualmente, el conten y el diseñador encarna el papel de u somo un carpintero que toma la forr

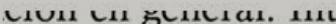
un signizar la forma para e] ambio eni ede inferieptual por las oríge n ". (Rafaəla, el objeto, la exp y gradua istoria, porque exist n danza adas sus raíces. De: en conceptual y do] sible. Dis $r$ diseñado, como do, las icevolando la inmanı ropio pri diseñar, $r$ ¥ forma al prima e lengua olvi

ese textos nrncesr a un trnzo ue construí ese discurso, he hecho de ara un reconfiguración de significado en para ilustrar... (en construccion) antiguas formas, es lanzar al mundo 1. La responsabilidad aquí se hace stamos elaborando, significados para

um mundo complexo. São Paulo,

1 agosto). Significado. Recuperado 1 $\mathrm{br} /$ significado/ 


\title{
When is Architecture not Design?
}

\section{¿Cuándo no es la arquitectura diseño?}

\author{
Saul Fisher ${ }^{*}$
}

\begin{abstract}
If there is nothing more to architecture than design -and to its attendant thinking processesthan design thinking, then core dimensions of the architectural enterprise from the perspective of (a) production and (b) use have no special character, over and above their counterparts in general design. Yet that does not appear to be true by the lights of architects or design specialists or the public at large. So what is it, at the core or periphery of the discipline or its objects, that makes architecture not design? The ways in which architecture and design constitute artistic enterprises, drawing on and promoting aesthetic interest, differ such that architecture is not, or at least not only, a branch of or variation on design generally construed.
\end{abstract}

Keywords: architecture, design, "design thinking", architectural objects, cognitive norms.

\begin{abstract}
Resumen
Si no hay nada más en la arquitectura que el diseño -y sus procesos de pensamiento concomitantesque el pensamiento sobre el diseño ("design thinking"), entonces las dimensiones centrales de la práctica arquitectónica desde la perspectiva de (a) la producción y (b) del uso no tienen un carácter especial, más allá de sus contrapartes en el diseño en general. Sin embargo, eso no parece ser cierto bajo la luz de los arquitectos o especialistas en diseño y el público en general. Entonces, ¿qué es, lo que hace que la arquitectura no sea diseño ya sea en el núcleo o la periferia de la disciplina o en sus objetos? Las maneras en las que la arquitectura y el diseño son prácticas artísticas, aprovechando y promoviendo el interés estético, difieren de tal manera que la arquitectura no es, o al menos no sólo es, una rama o variación del diseño como generalmente es entendido.
\end{abstract}

Palabras clave: arquitectura, diseño, "design thinking", objetos arquitectónicos, normas cognitivas.

A common view, in the public mind and from the perspective of some design specialists, has it that architecture is a brand of design, namely, the brand dedicated to designing the built environment. So, too, architects frequently speak of their central task in addressing architectural problems as 'designing', with the produced objects of their creativity cast as 'designs'. This much suggests that, at least as popular and specialized nomenclature has it, architecture is a special case of design (and correspondingly, that architectural objects are special cases of design objects, that architectural thinking is

* Mercy College, Estados Unidos. sfisher@mercy.edu

Articulo recibido: 1 de julio de 2019; aceptado: 17 de octubre de 2019 
a special case of design thinking, and so on). This subsumption of architecture into design, however broadly held or otherwise evidenced, nevertheless leaves a puzzle. If there's nothing more to architecture than design, and to its attendant thinking processes than design thinking, then core dimensions of the enterprise from production and use angles -architectural ethos, norms, creativity, appreciation, evaluation, and judgmenthave no special character over and above their counterparts in general design. Yet that does not appear to be true by the lights of architects or design specialists or the public at large. So what is it, at the core or periphery of the discipline or its objects, that makes architecture not design? This question may be posed relative to any number of aspects of architecture and design -social, professional, economic, pedagogic, and so on- but my focus is on aesthetic and artistic dimensions of architecture and design. The ways in which architecture and design constitute artistic enterprises, drawing on and promoting aesthetic interest, differ such that architecture is not, or at least not only, a branch of or variation on design generally construed.

To begin with, consider the space of possibilities. As a first thought, we can call 'architectural autonomism' the view that architecture as a discipline is distinct from, and not dependent on, general design as a discipline. The two disciplines may be related in some ways -for example, one may generate ideas taken up in the otherbut they have no essential bond or at least none that is definitive of the respective enterprises or joins them as one, even in part. By contrast, the anti-autonomist views include at least these options: (1) that architecture (a) simply folds into general design (d) (or, as mereologically notated, $\mathrm{Pad}$ ); (2), that design generally simply folds into architecture $(P d a)$; and (3) that architectural design can range over all other artifactual design, there being some but incomplete overlap (Oad). Let's call the Pad view 'design imperialism', and the Pda view 'Loos' foil', in honor of the Adolf Loos parable in which he mocks the architect who fashioned an exhaustive and exclusive design concept, forbidding his client from adding anything to his house. Let's call the Oad view 'spoonism', in honor of the twentieth century tradition among some architects of seeing their discipline as licensing design of all manner of artifacts, 'from the spoon to the city' (discussed below). ${ }^{1}$ There may be other variations on these possibilities; the point is to illustrate multiple ways in which autonomism can be wrong, as have indeed been asserted in various quarters. Naturally, depending on various facets of architecture and design as disciplines, there are multiple ways for autonomism to be right, as well -but I am interested in one particular path to autonomism. I argue that the core of architecture and design as disciplines is their respective sets of approaches to or ways of thinking about certain sorts of problems for which architectural objects and design objects, respectively, represent putative solutions. Further, as reflected in the fundamentally distinctive nature of the kinds of objects created in each discipline, there is a crucial lack of overlap (disjointness) in the problems these disciplines address. Their sets of approaches to or ways of thinking about such problems -that is, their respective cognitive norms and modes- differ accordingly, ruling out the possibility that architecture is a subspecies of a broader design discipline.

1 Mereologically, we can take autonomism as $\neg$ Oad (or, given disjointness as a predicate, Dad), as well as a significant instance of $\mathrm{Uad}$ (underlap) if we assume that, while architecture and design are autonomous, they also both belong to a coherently defined meta-discipline. 


\section{What is design -and is what architects do just that?}

To understand what is plausibly thought to be subsumed under what, I begin with a brief definition of architecture and a slightly less brief definition of design, both in disciplinary terms. ${ }^{2}$ We can stipulate, concisely, that architecture as a discipline is the planning for constructing the built environment, with special attention to built structures as may be habitable or otherwise occupied for the conduct of living, and as informed by aesthetic, functional, social, and other concerns and preferences. By this token, we typically think of architecture as primarily concerning free-standing buildings and the plans for them -e.g., Gaudí's Sagrada Familia in Barcelona (1882-present) or the mud brick tower houses of Shibam, Yemen (16 ${ }^{\text {th }}$ century). Secondarily, if keenly, we think of architecture as including or at least informing urban planning (e.g., Baron Haussmann's Paris renovation (1853-1870)), landscape planning (e.g., Frederick Law Olmsted and Calvert Vaux's Central Park in New York City (1858-1876)), interior planning (e.g., Louis-Charles Boileau and Gustave Eiffel's interior stairways for Bon Marché in Paris (1876)), or planning for other, related elements of the built environment.

The discipline of design, far broader in remit, is in its most general sense not tied to particular environments, sorts of structures, end-uses or end-users, or necessarily as informed by the same sorts of concerns and preferences as are central to architecture. The fabulously diverse domains of design stretch from clothing to code to milk cartons. With such extensive scope, defining design requires a greater level of abstraction, which we find in recent discussion in the philosophy of design. Here I follow, en gros, the views of Glenn Parsons (2016) and Andy Hamilton (2011).

Parsons, for his part, defines design as

1. intentional solution of a problem,

2. by creation of plans for a new sort of artifact,

3. where those plans would not be immediately seen by a reasonable person as an inadequate solution.

Correspondingly, the artifacts so created (a) solve problems, (b) are intentional, (c) consist in plans, (d) describe how to make or generate 'a new sort of thing', and (e) pass a reasonable plausibility test. The hallmark of Parsons' definition is a greatly accommodating picture of what sorts of artifacts can be designed, with a focus instead on what sort of activity or pursuit is common to all designers -namely, a kind of practically-oriented problem solving ideation. As we will see, one or another variation on this theme is extremely common in the design literature and community.

This theme is also, however, insufficient to understanding how the design discipline is commonly understood, namely, as an aesthetic enterprise. To find this aspect of design as a discipline, we turn to the definition offered by Andy Hamilton, who proposes that design comprises constructions with a central role for the aesthetic, as realized in visual, sonic, or haptic qualities. ${ }^{3}$ We can profitably put together Parsons'

2 Design is a more diffuse discipline -we know this in part just in virtue of considering the possibility that architecture might be subsumed under it- and design as a discipline is also of more recent vintage, and pursued in more diverse domains, than architecture, as traditionally conceived. A briefer thought about defining architecture may suffice in ways that would not for design.

3 Parsons rejects this view as not excluding the non-design arts, and as needlessly excluding non-artistic design, as in engineering. Parsons suggests that instead that the distinguishing feature of design (as against engineering or crafts or manufacturing) consists in the normative features of designer practice relative to practicality, user interface, and plans conception (21-24). 
and Hamilton's two views, to account for specifically artistic design. Then we get:

PHDesigns are intentional plans to solve aesthetic as well as functional problems, as engage with the senses and as may be characterized as novel and plausible. lines:

A ready move to subsume architecture under design presents itself, along these

PHA Architectural designs are intentional plans to solve aesthetic as well as functional problems of housing or other habitable spaces, as engage with the senses and as may be characterized as novel and plausible.

We can imagine more refined versions of PHA that specify in greater detail the sorts of problems that architecture addresses. In the limit, these versions will draw our attention to the many similarities that hold between the architectural and design disciplines, such as characterize (for example) their respective techniques or institutionally-designated standing qua disciplines. Thus, architecture like design draws on abstract representation through mock-ups and models -whether plastic or virtualthat prototype structures to be realized through craft or manufacture or other form of assembly. Further, architecture is frequently seen through institutional lenses -in museums, scholarly literature, journalism, and university curricula- as being allied with, or even inseparable from, the aesthetic concerns of design generally and taking up a similar or same corner of the arts -to wit, the design corner.

Yet, however refined a version of PHA as we may devise, with its attendant similarities among the disciplines, it will be wrong in two ways, one reflecting contingent facts and another on a more fundamental, conceptual plane. The contingent facts concern the practices, objects, and history of ideas in architecture and in design -I briefly review how these are distinctive and in non-trivial ways. The fundamental, conceptual story is grimmer still for the anti-autonomist: the discipline of architecture, independent of histories and cultures, aims at goals that are regularly -and likely nearuniversally- distinctive from those of design generally considered. ${ }^{4}$ As a consequence, the modes and norms of architectural cognition are not identical to those of design cognition and, per Parsons' view of the centrality of design thinking to defining design, architecture cannot be folded into design.

\section{Contingent Differences: Practices, Objects, and History of Concepts}

The contingent differences between architecture and design that I have in mind are found in the ways those disciplines are pursued professionally, the sorts of artifacts for which they provide plans or designs, and the historical discussions of each discipline. While such matters are not my core focus, they help to identify what I take to be key and ineliminable distinctions between architecture and design.

Professional practice. From a professional perspective, there are any number of similarities between architecture and design. Both are, in the main, market-driven pursuits or disciplines, although design is more directly and genetically so (see 'History of concepts', below). In both disciplines, practitioners engage with classical texts of the field that address theoretical problems and raise enduring questions, to grapple with and

4 There are exceptions and in any case one should hesitate to talk about universality among the disciplines, as socially-constructed kinds. But as such kinds go, there are distinctions in this case of a compelling, enduring, and rational character such that one would expect the distinctions, mutatis mutandis, to remain more or less in place. 
bring to life their intellectual heritage. ${ }^{5}$ And, typically, practitioners in both disciplines do not directly realize their schema or plans -designers are rarely manufacturers, and architects are rarely builders.

On the other hand, while professional design features some activities associated with professional architecture, only architecture features universal and legal responsibilities as pertain to documentation, contractual tasks, or post-construction services. In these ways, architecture is a more complex profession. So, too, are architecture's complexities greater for the prescriptive or normative character of the discipline. Architects are committed to conceiving how the built environment should look, act, and feel (Leatherbarrow, 95). The design discipline, by contrast, has a far weaker commitment in these regards -another indication of the greater extent to which design is driven by consumer preference, even as design contributes to such preference-formation.

Objects of the domain. In architecture and design alike, objects of the domain comprise the realized (built, assembled, or manufactured) objects along with the plans for their realization, and -on one construal- the ideas those plans represent, too. Moreover, plans in both domains similarly constitute prospective representations of imagined, future artifacts - moreover, in both domains such representations allow the viewer access to structures and aspects that cannot be naturally seen, as in crosssections or unusual perspectives (Leatherbarrow, 2001, 89). Although basic outlines of an ontology may appear as roughly parallel across the two domains, there are differences, as well -among both plan-objects and realized objects.

As concerns plan-objects, the main differentiating aspect of architectural representations (as against design drawings), is that owing to sheer scale and multiple levels of detail, such representations are often compound entities (such as sets of multiple drawings) or collections of perspectives dynamically generated by drawing on complex data sets (as in CAD or BIM representations). Only by taking together the full set of such representations might we have access to the entire imagined structure, and even then we may only be accessing a fragment of the whole (Hill, 1999; Leatherbarrow, 2001).

As concerns the realized objects of architecture and design, one prominent similarity in the present era is that each enjoys relations to industrial production, although historically design is almost exclusively so related. As Rappoport (2009) has noted, this close, even genetic, relationship of design to industrial production has the consequence that design objects are by their nature replicable in practice. By contrast, whereas in principle built architectural objects may be replicable -conceivably as essentially so- in practice replication rarely occurs outside of public housing or suburban developments., Other, more trivial differences among objects of the two domains typically include scale or breadth of utility. Further and more significant distinctions reflect the stable, lasting, and continual value of built structures as compared with manufactured commodities or consumer goods. Thus, whereas design is often quotidian and even more often does not age well (e.g., from plastic shopping bags

5 In architecture, for example, classical texts include Alberti's De re aedificatoria (1443-1452), or Mimar Sinan's autobiographies (Adsız Risale, Risāletü'l-Mímāriyye, Tuhfetü'l-Mi'mārīn, Tezzkiretüll-Ebniye, and TežkiretüllBünyān) (c 1588); cf. Crane, Akın, and Necipoğlu, 2006. In design, for example, classical texts are of more recent vintage and include Dresser, The Art of Decorative Design (1862) or Tschichold, Die Neue Typographie (1928). 
to ocean detritus, within weeks), architecture often aspires to create structures that aesthetically transcend their particular era and are built to last (e.g., Pyramid of Khufu at Giza (c2580-2560 BCE, or Angkor Wat (12 ${ }^{\text {th }}$ century CE). In general, architecture is not oriented towards obsolescence and instead may generate value in re-use and even in ruins (Rappoport, 2009). Yet other differences consist in the tendency of architectural objects to interact with environmental conditions and to shape space (as design objects do not), and the greater degree to which architectural objects are static and grounded in the earth; these are, however, tendencies and by degree (Rappoport, 2009).

Even as tendencies or by degrees, however, these sorts of distinctions among realized objects of architecture and design give some suggestion as to how to think about differences among the disciplines. ${ }^{6}$ If architectural objects are generally conceived of and planned for relative to long timespans, as rooted in their sites, and maintaining value over the long haul, they may feature, or require, qualities that do not pertain in the case of other, more quotidian and obsolescence-prone objects, and the ways that we approach their design may vary accordingly -perhaps systematically.

History of concepts. The histories of these two domains, loosely understood as matching to their modern disciplines, intertwines from earliest times, as seen in compendia, manuals, or other recordings of different ancient or antique traditions. ${ }^{7}$ As a modern discipline dedicated to commodity and consumer goods, design has a very recent history, rendering its traditions entirely and distinctively of recent vintage in ways that cannot be attributed to architecture, with its clear ancient roots. Design was born of the mercantile and manufacturing world of mid-eighteenth century Europe, with concomitant motives of meeting manufacture, market, and consumption needs. Design as a discipline was initially intended to augment the look, feel, build, and durability of goods, in order to signal their overall quality and thereby represent added value, drive taste, and advance socially-promoted preferences. ${ }^{8}$

Despite clear differences among the domains, distinguishing architecture from design over the course of history is muddied by several considerations. First, prior to the birth of modern design, architecture was seen as executed through design in the sense that Vasari (1568), among others, indicated: the '...visual expression of the concept" of the artist or architect. This use of 'design' -shortly thereafter transformed slightly to stand for 'building schema' or 'plans for built structures', or even 'ideas for built structures'- quickly gained currency in architectural writing. ${ }^{9}$ In some such writings, there have been notable attempts to define 'design' as indicating a particular

6 Such tendencies can be categorically determinative even as tendencies. For example: Design objects appear to be more generally what we might call maniable artifacts $(M)$, as compared with architectural objects, which more closely resemble rooted, structural artifacts $(R)$, where an artifact is $M$ iff it can be held, moved, or is pliable; and an artifact is $R$ iff it is not maniable. Now, not all structures in the built environment are Rs. Notably, transient and nomadic populations build in temporary ways sometimes to be re-created after transport (e.g., teepees); others not. That some elements of the built environment are $M$ or hybrids of $M$ and $R$ does not mean, of course, that they are not architecture. But it might mean that their design framework is, at least in part, shaped by and characteristic of non-architectural design.

7 On Greek architecture and design, cf. Vitruvius (15 BCE); on Indian architecture and design, cf. Mānasāra ( मानसार ) (sixth to eighth century CE; Acharya, 1928); on Chinese architecture and design, cf. Yingzao fashi (營造法式) (eleventh century CE; Feng, 2012). The link of Aztec architecture to design is harder to discern in writings but imagery in codices is suggestive; cf. García Ocampo Rivera (2016).

8 Cf. Sir William Chambers (1759/91), 75; Forty, 140.

9 Cf. notebooks of the seventeenth century British architect Roger Pratt (1928), who refers to designs and drafts synonymously. 
sort of architectural idea, whether related to composition (Soane, 2000); the specifically unconstructed or not-yet constructed (Scott, 1914); or the intellectual and immaterial, as characterized architectural practice increasingly divorced from construction in modern times. ${ }^{10}$

Second, after the birth of modern design, architects -individually or especially in groups and movements- have occasionally taken a great interest in pursuing design as integrated, to some degree, with architecture. Indeed, the word 'design' gained increasing currency in professional architectural circles in the West over the course of the twentieth century, as emblematic of growing interests of architects beyond the built environment and buildings in particular. Among numerous such instances, Joseph Hudnut organized all architecture-related disciplines at Harvard University into the Graduate School of Design, and in the following year brought in as Chair of the Architecture Department Walter Gropius, who subscribed to the slogan "from the spoon to the city". This slogan ("dal cucchiaio alla città"), was initially formulated by the Italian architect Ernesto Nathan Rogers (1946), as based on the similar adage, "from sofa cushions to city building" ("vom Sofakissen zum Städtebau"), formulated by the German designer Hermann Muthesius some years earlier, in announcing the Deutscher Werkbund remit $(1906,1912) .{ }^{11}$ The core notion is that architects can design at all scales, from the very small to the very large, inclusive of the standard built structures which fall somewhere in the middle of the fullest scale. In Buckminster Fuller (1949), we find a similar view, promoting 'comprehensive design', the idea that all facets of life and instruments for living are subject to design, through the guidance of social science, materials engineering, and systems analysis. Such efforts range widely -from Charles Rennie Mackintosh's nearly-practical Hill House chairs (1902) to Archigram's phantasmagoric cities of the future (1960s)- and there is no principled or practical obstacle to such pursuits in a 'spoonist' key, or overlap of architecture with design at all scales. Nor, however, is there anything in those efforts or their advocates that suggests an inherent or even compelling persistent link between the disciplines.

These differences in architectural and design practices, objects, and histories, give us ample reason to suspect PHA or anti-autonomism more generally, as contingently false. The notion that architecture is a branch of design reflects neither how the two domains or disciplines have developed, nor how they relate to one another at present; moreover, objects of the two domains frequently differ in character and nature. However, there is a yet more compelling reason to see architecture as autonomous from design, rooted in the ways that each discipline is pursued, according to what might be thought of as ways of thinking, or cognitive norms, of their respective professions.

\section{Disciplinary cognitive norms: What are design thinking and architectural thinking?}

All these differences affect the nature of architecture and design as disciplines, with

10 Cf. Forty, 137-138

11 Muthesius' Werkbund conception offered a variation on earlier motivation for design of commodities and goods: industry can mass-produce culture and art to bring standardization to manufacture of goods of increasing and intentional aesthetic quality and so promote consumption of ever-greater value. In short, aesthetic qualities continued to represent added value, but also stand as an intrinsically good quality of the manufactured product. A similar notion was adopted by the Bauhaus (as advanced by Walter Gropius and others) and by the Ulm School of Design, as advanced by Max Bill (1954); cf. Kostešić (2017). 
their attendant ways of viewing the world, of collecting and analyzing information, and of applying resulting insights to planning or designing for new artifacts that contribute to aesthetic and functional betterment. Yet it seems unlikely to devise a detailed causal mapping of contingent features of architectural and design practices to the essence of architectural practice or of design practice, if only because it seems unlikely that those practices have any such essences. There are nevertheless marks of distinction among those different practices, which we can see more readily if we take their primary charges as modes of identifying problems and seeking solutions to them. This is a notion at the heart of Parsons' view of design -therefore, as well, of PH and PHA- and reflects the package of concepts, in design literature old and new, of 'design thinking'. Much, though not all, of the history of that literature is intertwined with reflections on design thinking as specific to architecture, and teasing the two apart can be difficult. Here I assume that such literature is, on the whole, primarily intended to address the nature of design thinking generally -and only secondarily, to address the nature of architectural design thinking. This turns out to be a reasonable assumption given attempts in more recent literature to identify hallmarks of design thinking specifically associated with architecture.

What, then, is design thinking supposed to be, and how did it evolve? A most general conception of design thinking is that it offers, alternatively, descriptive or normative accounts of the sorts of thinking, and norms governing such, relative to design of artifacts- where such design carefully tracks the identification and resolution of problems.

The older literature on design thinking (1960s) traces back to Herb Simon's The Sciences of the Artificial (1969) and Christopher Alexander's Notes on the Synthesis of Form (1964). For Simon, designing is a cognitive process of feedback loops in which the designer identifies problems to be addressed and potential solutions, that are next prototyped and tested, to facilitate artifactual creation and advance our understanding from performance -which ostensibly yields new problems to be solved. In his early work, Alexander also tries to identify the flow of cognition in design thinking, rendering the problem of planning a new artifact into parts: first, assessing what its required components would be; next, identifying their needed relations; and finally, developing plans for the whole new artifact as based on a fuller grasp of those constituent elements and their logical relations. In the later A Pattern Language (1977), Alexander and colleagues appear to have abandoned a cognitivist approach to design thinking, in favor of a culturally-bound repertoire of solutions to design problems -and yet, the notion persists that design consists in identification and resolution of problems. The difference, whether an advance or otherwise, is their suggestion that we can usefully generate design efficiencies by providing solutions of a standard and ready-to-use nature.

A next, more self-aware generation of design thinking theorists -Donald Schön (The Reflective Practitioner, 1983), Peter Rowe (Design Thinking, 1987), and Bryan Lawson (How Designers Think, 1990)- seeks to identify ways of thinking special to, and common across, all design processes. Some proposed elements in their conception of design thinking are still borrowed from broader cognitive strategies. Thus, framing the problem as an initial, defining stage, as coupled with a stage of relating new problems to prior catalogued experiences, resembles Minsky's notion of representing information per stereotyped situations (1974), along with other general cognitivist theories in a Kantian 
vein posing the mental structuring of experience. Other elements are more clearly attached to specifically design challenges. Notably, a central conceptual challenge in design concerns identification of solutions in scenarios where the attendant problems have themselves not been identified, at least perspicuously. This challenge has elicited a variety of responses; in Schön, we find the suggestion that designers draw on imagination and intuition to creatively identify the broadest dimensions of a problem space ('divergence'), before focusing on prospective solutions ('convergence').

A third generation of design thinking research forks into practical, managerial advocacy on one hand and empirical studies on the other. On the advocacy side, design thinking incorporates a utility calculus -typically gauged at the individual level (particularly relative to product design) but with the assumption that in the aggregate, this totals to broad social utility. ${ }^{12}$ A further step, towards social cognition of design, has it that- along with traditional product design- problems of management, policy, and other social character can be addressed through iterative cycles of ideation and execution (Brown and Wyatt (2010); Kelley (2001)). Finally, recent empirical studies assess design thinking as specialized cognitive operations and practices, as iterations of the familiar range of such operations: gathering, storing, and retrieving information; analyzing and reasoning; accumulating and representing knowledge; developing ideas and understanding; and directing actions on the basis of intentions and synthesized understanding. Specific research in this tradition centers on such dimensions of design cognition as development of design expertise (cf. overview in Cross, 2018); apportionment of cognitive tasks over time in a given design process (cf. Huysentruyt, Lespinet-Najib, and Chen, 2012; Alexiou, Zamenopoulos, Johnson, and Gilbert, 2009); roles of the visual or of drawing in design thinking (cf. Goldschmidt, 1994); analogy, nonlinearity, or divergence in design thinking (cf. Özkan and Dogan, 2013; Nguyen and Zeng, 2012; Bila-Deroussy, Bouchard, and Diakite Kaba, 2015; and Goldschmidt, 2016); and sources of creativity and individual style (cf. Chan, 2015).

Over generations of reflection on design thinking-and particularly in contemporary empirical study- the scope of design cognition seems sufficiently broad as to range over whatever might be thought of as architectural design thinking. Indeed, some prominent design thinking scholars, as architects themselves, take architecture as the base case in design. Indeed, conceptions of architecture as focused on problem-solving are much older than the mid twentieth century design thinking tradition; as Plowright notes $(2014,25-26)$, we find talk about problem-solving in Serlio $\left(16^{\text {th }}\right.$ century) and Durand (1802-1805). More to the point, design thinking and its constituent cognitive tasks are described in intentionally abstract terms, so as to capture the broadest range of design domains and tasks. But this level of abstraction carries a risk of skimming over important and distinctive features of the given domains that span all fields in which design plays some role. This, it turns out, is true of architecture: there are aspects of architectural thinking that are so distinctive as to not be captured in design thinking.

What is architectural thinking? One tack in defining architectural thinking as distinctive is to start with the generalized problem-solving conception of design disciplines and show that architecture does not fit that conception. This is Plowright's strategy; he argues that architectural projects do not have discrete or 'containable' 
character -rather, per Rittel \& Webber (1973), such projects are typically 'wicked' problems. Further, the situation or scenarios that architectural projects address are not really solutions, after all, because they do not correspond to actual problems (Plowright, 26). Instead, Plowright says, architectural projects are responses to sets of "pressures, forces, perceptions, desires, priorities, and values" (26). What he is alluding to here as forcing non-discreteness, non-containability, and non-problem status is the extraordinarily complex nature of architectural competitions, requests for bids or proposals, and other contemporary scenarios in response to which project designs are created. The responses so crafted, Plowright proposes, are far greater in complexity than design solutions focused on 'merely' aesthetics or functionality.

Plowright's alternative picture of architectural thinking features three principal modes in which architects appeal to different norms for reasoning and starting points. First, he suggests, architects appeal to patterns and rules to determine the design; Durand (1802-05) is an early proponent and Christopher Alexander et. al. (1977) are late proponents. Second, architects appeal to a norm-guided negotiation of forces, both internal and external to the project and planned structure, as may characterize systems comprising the structure and its context -and as prompt navigating opportunities and constraints that complex projects present. Pertinent historical cases include construction of the Centre Pompidou (Beaubourg) in Paris (Renzo Piano and Richard Rogers, 1971-77) and the first and second World Trade Centers in New York (One and Two World Trade Center, Minoru Yamasaki, 1968-71; and One World Trade Center, David M. Childs (SOM), 2006-13), or reconstruction of Potsdamer Platz (Renzo Piano, Hans Kollhoff, Richard Rogers, Helmut Jahn, Rafael Moneo, et. al., 1991-present). Multidimensional cases like these show how architects gauge competing interests, preferences, and needs of varied stakeholders (as well as site- or use-specific concerns), requiring not merely sensitivity, perspective, and tact -but also adherence to rules of political engagement and negotiation, such as reciprocity, trust, fairness, or objectivity. And third, architects appeal to some central, overarching concept that drives all design or other considerations, such as are associated with ideologies like Modernist formalism or, more generically and traditionally, the parti or simple guiding idea as initially identified in the design process. Each of these norms and starting points for architectural reasoning has a variety of historical and contemporary advocates, and in the architectural design process each may be used with others, non-exclusively. That said, it is the second sort of appeal, with its emphasis on normative negotiation of forces relative to a system, that Plowright poses in particular as the sort of thinking that architects pursue in response to the complexity of scenarios they address, particularly in light of the public engagement of architects.

There is much that is correct in Plowright's proposal: as an empirical matter, these are among the norms and starting points for architectural reasoning. That said, it is not clear that these are sufficiently distinctive to separate architectural reasoning from other or generic design thinking. For one, the challenge of navigating "pressures, forces, perceptions, desires, priorities, and values" is a sort of problem, albeit of possibly varying complexity by degrees, and perhaps even by kind, frequently encountered in product, commercial, or other design. Thus, movements for socially-responsible and participatory design promote design processes that are user-engaging and communitybased, culturally and ethically sensitive, and welfare-maximizing (Papanek, 1973; Margolin and Margolin, 2002; Bannon and Ehn, 2012; Clark, 2013). The products 
of such processes optimally advance quality of life and avoid costs to humanity (e.g., energy-efficient transport or low-cost prosthetic limbs). But at all events they should demand awareness of norms for negotiating diverse interest and perspectives. Accordingly, what for Plowright represents the most distinctive aspect of architectural reasoning ends up as no more distinctive than a special sort of problem-solving in the classical framework of design thinking.

For another, while architecture features a notable complexity or non-discreteness (wickedness), it's not just those features that distinguish architecture -if they distinguish it at all- from design generally. For truly distinctive features of architectural practice and reasoning, we would do well to look at the distinctive nature of architectural objects. A different tack, then, to identifying specifically architectural thinking follows a bottom-up approach. We start with distinguishing features of architecture and see what those require in architectural thinking -and as may be unavailable in design thinking generally.

As noted in section two, numerous features of architectural objects -particularly among realized, built structures- distinguish them from other sorts of artifacts. In consideration of some such features -and yet other distinctive features of architectural objects- architectural thinking also takes on a distinctive character. Such features of built architectural objects include their (1) capacity for spatial structuring and for environmental impact (traffic, flow, and other behavior); (2) persistent, diverse, fullbody engagement of people; (3) interconnectivity with other architectural objects, to jointly constitute networks of architectural objects and topographical and social context; and (4) prospectively lengthy lifespan and flux over that lifespan. All these features in turn motivate a fifth feature -but of architectural representational objectswith potential to drive distinctive sorts of reasoning in architecture. This fifth feature is the quality of architectural plans of being neutral, open, or extensible so as to accommodate future activity, behavior, choices, and change. Architects need plans to be not-fixed, to the greatest extent possible, to account for the nature of built architectural objects lasting for what may be a very long time, with the various capacities for openended engagement with users and surroundings even during the planned program for the built objects, and with re-use possibilities that are perforce unknown. Plowright is correct to highlight the non-discrete and non-containable nature of architecture; however, his focus on those features of scenario prompts (in effect: design challenges or problems) doesn't provide architectural thinking with a mark of distinction. The non-discrete and non-containable nature of the possible responses or solutions -that is, built architectural objects and their corresponding plans- however, does.

\section{Architectural Thinking as Distinctive}

In light of these special features of architectural objects, at least two aspects of architectural thinking distinguish it from design thinking generally.

For one, the open-ended, indeterminate nature of the life of a built structure means that architectural thinking should allow for recalibration of the knowledge base, of understanding, and of ideas regarding that structure. This is to accommodate new information introduced at any stage of the designing process or subsequent to it, from construction through the course of the structure's lifespan. For example, architects routinely orchestrate on-site changes as prompted by site- or construction-driven needs 
and requirements. ${ }^{13}$ A designer of pencils or wall brackets has a limited role in this regard-limited, that is, by the nature of the objects, their expectable re-use and life cycle, and their manufacture (and patent rights) as much as by anything else. Design thinking likely incorporates feedback on something like the Simon model, but does not incorporate recalibration as in architectural thinking. ${ }^{14}$ The recalibration built into architectural thinking anticipates and facilitates re-use over the long haul-namely, for the same designed artifact, at least as concerns the same version.

For another, and of greater import, design and architecture feature entirely different sorts of solution-types. General design produces schema for broadlyapplicable, complete, and fixed solutions to problems. Thus, for example, the designs for the Helvetica font (Max Miedinger and Eduard Hoffman, 1957) or the K-brick (Anna Keichline, 1927) addressed practical challenges with design solutions that were deployable across a wide variety of contexts, because mass produced and simple to distribute; were self-contained, in that execution on the design realized or produced the whole item; and non-extensible, in yielding more or less the functionality for which they were designed -and no more. Not all of general design may have all of these features yet they appear to be broadly characteristic. It is a further question as to whether such features represent constraints on aesthetic intentions or appreciation relative to general design, as much as they do on the functional character of designed objects.

By contrast, architecture produces plans that (a) while they may be broadly applicable, also may only be applied once and in a given context; (b) may be incomplete solutions; and (c) are almost never fixed solutions. As concerns (a), built structures may come in multiples but even an architectural plan specifying multiple structures may only eventuate in one instance being realized. As concerns (b), the incompleteness of architectural solutions is evidenced by the contributions of contractors in contemporary construction, who make any number of changes to build structures under development, as supplemental to highly detailed specifications drawn up by architects. ${ }^{15}$ And as concerns (c), every extension ever added to a house, castle, factory, or museum is a case of what was, in its initial plan, a non-fixed solution to the initial design challenge. All such cases point to solution-types that shape architectural thinking as approximations addressing an indefinite future, in contrast with solutiontypes that shape design thinking as viable schema for present use and experience.

13 As Leatherbarrow notes, Vitruvius himself highlights the role of architects in making adjustments to buildings under construction.

14 One regular exception here is code design, which often shares with architecture the characteristic feature of open-ended, indeterminate life-cycle -though typically in the case of code, lifecycle is far more constrained than in the architecture case, by external factors such as rapid change in programming environments, viz. platforms and languages.

15 What architects call 'design intent' illustrates the incompleteness of solutions in architectural design (Grondzik 2004). The intent is more detailed than the project programme or brief, which outlines the nature of the structure to be built and the basic goals and requirements for the building project. Further details of design intent spell out how, from the architect's perspective, the built structure would realize those goals and meet those requirements in the resulting spaces, with the forms so created, and in terms of necessary systems. All of this, however, is significantly less detailed than more granular solutions provided in further stages of defining technical specifications ('specs') and construction or contractor details. There is, in fairness, a great deal of flux historically and at present as to where the architect's job ends and the technical detailer's job begins. Yet the basic notion of design intent is that the architect's core design idea is at a level of detail that, being highly incomplete, allows for multiple -perhaps very many -modes of realization. 


\section{Conclusion}

In light of the nature of its objects, representational or built, architecture has at least these attendant cognitive norms: requiring recalibration in thinking about plans for a given built structure, and reasoning to solutions that are incomplete or non-fixed. Given the $\mathrm{PH}$ view of design, those norms appear sufficient to embracing autonomism. The problem for the anti-autonomist, in short, is that design cannot subsume architecture if design thinking cannot accommodate all of architectural thinking, and architecture's varying cognitive norms indicate that such accommodation is not possible.

On the other hand, it may be thought that, rather than taking these features of architectural objects and architectural cognitive norms, plus the $\mathrm{PH}$ view of design, as evidence for autonomism, we should sooner throw out or amend $\mathrm{PH}$ (or, in particular, Parsons' view). Thus, given the open-ended nature of architectural solution-types that drives a sort of reasoning distinctive to architecture, Parsons' plausibility test is not easily gauged in the moment, at creation of the plan or schema -and is nearly impossible to gauge for the long term- in light of the high incidence among built architectural objects of re-use, disuse, destruction, or even simpler changes. On the other hand, many built structures last over great timespans and many more still are built to do so. So the very notion of a plausibility test may be untenable, if we insist that architectural reasoning is a species of design reasoning generally.

That approach, however, requires tinkering with a view about the nature of design that appears to cover just about all standard cases, once we exempt architecture from the ranks of general design. Aside from posing a less costly solution, we have ample reason to take architectural objects, the solution-types they represent, and the corresponding cognitive norms of architecture, as distinctive enough to mark them as autonomous from design as a whole.

\section{Bibliography}

Acharya, P. K. 1928. Indian Architecture according to Mānasāra-śilpaśāstra [Mānasāra English trans.]. London: Oxford University Press.

Alexander, C. 1964. Notes on the Synthesis of Form. Cambridge, MA: Harvard University Press.

Alexander, C., Ishikawa, S., \& Silverstein, M. 1977. A Pattern Language: Towns, Buildings, Construction. Oxford and New York: Oxford University Press.

Alexiou, K., Zamenopoulos, T., Johnson, J. H., \& Gilbert, S. J. 2009. "Exploring the Neurological Basis of Design Cognition Using Brain Imaging: Some Preliminary Results", Design Studies, Volume 30, Issue 6: 623-647.

Bannon, L. J. \& Ehn, P. 2012. "Design Matters in Participatory Design", 37-63, en J. Simonsen \& T. Robertson (eds.). Routledge International Handbook of Participatory Design. London and New York: Routledge.

Bila-Deroussy, P., Bouchard, C., \& Diakite Kaba, S. 2015. "Addressing Complexity in Design: A Systemic Model of Creativity and Guidelines for Tools and Methods". International Journal of Design Creativity and Innovation, Volume 5, Issue 1-2: 60-77.

Brown T. \& Wyatt J. 2010. "Design Thinking for Social Innovation", Stanford Social Innovation Review,

https://ssir.org/articles/entry/design_thinking_for_social_innovation.

Chambers, W. 1825 [1759/91]. A Treatise on the Decorative Part of Civil Architecture. London: Priestly and Weale. 
Chan, C.-S. 2015. Style and Creativity in Design. Springer International Publishing.

Crane, H. \& Akın, E. (eds. and trans.); Necipoğlu, G. (intro.). 2006. Sinan's Autobiographies. Five Sixteenth-Century Texts. Leiden: Brill.

Clark, B. 2013. "Generating Publics through Design Activity", 199-215, en W. Gunn, T. Otto, \& R. C. Smith (eds.). Design Anthropology: Theory and Practice. London and New York: Bloomsbury Academic.

Cross, N. 2018. "Expertise in Professional Design", 372-388, en K. A. Ericsson, R. R. Hoffman, A. Kozbelt, \& A. M. Williams (eds.). Cambridge Handbook of Expertise and Expert Performance ( $2^{\text {nd }} e d$.). Cambridge, UK: Cambridge University Press.

Dresser, C. 1862. The Art of Decorative Design. London: Day and Son; 1977. Reprint edition, New York: Garland Publishing Company.

Durand, J.-N.-L. 1802-05. Précis des Leçons d'Architecture Données à l'École Royale Polytechnique. Paris: chez l'auteur.

Feng, J. 2012. Chinese Architecture and Metaphor: Song Culture in the Yingzao Fashi Building Manual. Honolulu: University of Hawai'i Press.

Forty, A. 2000. Words and Buildings: A Vocabulary of Modern Architecture. London: Thames \& Hudson.

Fuller, R. B. 1949. "The Comprehensive Designer", 243-47, en J. Krausse and C. Lichtenstein (eds.). 2001. Your Private Sky: R. Buckminster Fuller Discourse. Baden: Lars Müller Publishers.

Goldschmidt, G. 1994. "On Visual Design Thinking: The Vis Kids of Architecture", Design Studies, Volume 15, Issue 2: 158-174.

— , 2016. "Linkographic Evidence for Concurrent Divergent and Convergent Thinking in Creative Design", Creativity Research Journal, Volume 28, Issue 2: 115122.

Grondzik, W. 2004. "Design Intent", 43, en Tom Porter (ed.), Archispeak: An Illustrated Guide to Architectural Terms, London and New York: Taylor and Francis.

García Ocampo Rivera, A. M. 2016. Towards an Understanding of Aztec Architecture and Urban Planning, doctoral dissertation, The University of British Columbia.

Garud, R., Jain, S., \& Tuertscher, P. 2008. "Incomplete by Design and Designing for Incompleteness", Organization Studies, Volume 29, Issue 3: 351-371.

Gropius, W. 1955. Scope of Total Architecture. New York: Harper \& Brothers Publishers. Hamilton, A. 2011. "The Aesthetics of Design", 51-69, en J. Wolfendale \& J. Kennett (eds.), Fashion-Philosophy for Everyone: Thinking with Style. London: Blackwell.

Hill, R. 1999. Designs and Their Consequences, New Haven, CT and London: Yale University Press.

Huysentruyt, J., Lespinet-Najib, V., \& Chen, D. 2012. "A Model of Cognitive Activities in Design", 9th International Conference on Modeling, Optimization \& SIMulation, Jun 2012, Bordeaux, France.

Kelley, T. 2001. The Art of Innovation: Lessons in Creativity from IDEO, America's Leading Design Firm. New York: Currency/Doubleday.

Kostešić, I. 2017. "Sveobuhvatni Dizajn: Podrijetlo i Razvoj Ideje" (Comprehensive Design: The Concept - Its Origin and Evolution), Prostor, Vol. 25, Issue 1 (53): 128-139.

Lawson B. 2005 (1980). How Designers Think: The Design Process Demystified, Fourth edition, Amsterdam and Boston: Architectural Press (Elsevier).

Leatherbarrow, D. 2001. "Architecture Is Its Own Discipline", 83-102, en A. Piotrowski 
and J. W. Robinson (eds.), The Discipline of Architecture, Minneapolis, MN and London: University of Minnesota Press.

Loos, A. 1900. "The Story of the Poor Little Rich Man", 124-127, en Newman, J. O. \& Smith, J. H. (trans.); Rossi, A. (intro.). 1982. Adolf Loos, Spoken into the Void: Collected Essays, 1897-1900. [Translation of A. Opel (ed.) 1921. Ins Leere Gesprochen: Gesammelte Schriften, 1897-1900. Vienna: Georg Prachner.] Cambridge, MA: Opposition Books, The MIT Press.

Margolin, V. \& Margolin, S. 2002. "A 'Social Model' of Design: Issues of Practice and Research". Design Issues, Volume 18, Number 4: 24-30.

Minsky, M. 1974. "A Framework for Representing Knowledge", MIT-AI Laboratory Memo 306 (June 1974), 95-128, en J. Haugeland (ed.). 1981. Mind Design. Cambridge MA: The MIT Press.

Muthesius, H. 1912. "Wo stehen wir? Vortrag, gehalten auf der Jahreversammlung des Deutschen Werkbundes", Jahrbuch des Deutschen Werkbundes: 11-26.

Nguyen T. A. \& Zeng Y. 2012. "A Theoretical Model of Design Creativity: Nonlinear Design Dynamics and Mental Stress-Creativity Relation", Transactions of the SDPS: Journal of Integrated Design and Process Science, Volume 16, Issue 3: 65-88.

Özkan Ö. \& Dogan F. 2013. "Cognitive Strategies of Analogical Reasoning in Design: Differences Between Expert and Novice Designers". Design Studies, Volume 34, Issue 2: 161-192.

Papanek, V. J. 1973. Design for the Real World: Human Ecology and Social Change. New York: Pantheon Books.

Parsons, G. 2016. The Philosophy of Design, Cambridge, UK and Malden, MA: Polity.

Plowright, P. D. 2014. Revealing Architectural Design: Methods, Frameworks and Tools. London and New York: Routledge.

Pratt, R. 1928. The Architecture of Sir Roger Pratt, Charles II's Commissioner for the Rebuilding of London after the Great Fire: Now printed for the First Time from His NoteBooks. R. T. Gunther (ed). Oxford: Oxford University Press.

Rappoport, A. 2009. “Архитектураидизайн-конфликтилимирноесосуществование?” (Architecture and Design - Conflict or Peaceful Coexistence?), en проект байкал (Project Baikal), архитектура vs дизайн (Architecture vs Design), Issue 22: 135137. doi:10.7480/projectbaikal.22

Rittel, H. W. J. \& Webber, M. W. 1973. "Dilemmas in a General Theory of Planning”, Policy Sciences, 4, 155-169.

Rogers, E. N. 1946. "Ricostruzione: dall'Oggetto d'Uso alla Città", Domus, 215: 2-5.

Rowe, P. G. 1987. Design Thinking. Cambridge, MA: The MIT Press.

Schön, D. 1983. The Reflective Practitioner: How Professionals Think in Action, New York: Basic Books.

Scott, G. 1914/1924. The Architecture of Humanism. New York: C. Scribner's Sons, 2nd edition; 1954. Reprint edition, Garden City, NY: Doubleday.

Simon, H. A. 1969. The Sciences of the Artificial. Cambridge, MA: The MIT Press.

Soane, J. 2000. Sir John Soane: The Royal Academy Lectures, Revised \& Abridged Edition. D. Watkin (ed.). New York and London: Cambridge University Press.

Tschichold, J. 1928. Die Neue Typographie: Ein Handbuch für zeitgemäß Schaffende. Berlin: Verlag des Bildungsverbandes der Deutschen Buchdrucker; R. McLean (trans.), R. Hendel (foreword), R. Kinross (intro.). 2006. The New Typography. Berkeley: University of California Press. 
Vasari, G. 1568. Lives of the Artists. 1991. J. Conaway Bondanella \& P. Bondanella (trans.). New York and Oxford: Oxford University Press.

Vitruvius. 15 BCE. De architectura; Ten Books on Architecture, 1914, 1960. M. H. Morgan (trans.), Cambridge, MA: Harvard University Press; New York: Dover. 


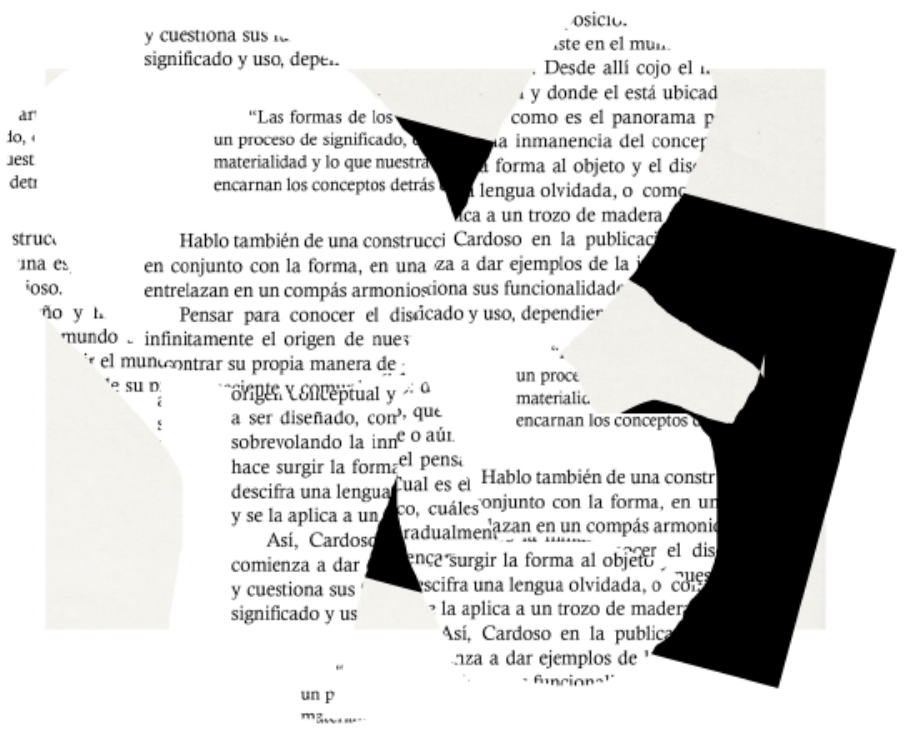

"Lo impreso exige una humildad de espíritu por cuya falta muchas de las bellas artes se tambalean ahora en experimentos de autoconciencia y sensiblería. No hay nada simple ni aburrido en lograr una página transparente. La ostentación vulgar es el doble de fácil que la disciplina".

Beatrice Warde, The Crystal Goblet, or why printings should be invisible (1930)

"El diseño que es objetivo, comprometido con el bien común, bien compuesto y delicado, constituye la base del comportamiento democrático".

Josef Müller-Brockmann, Grid and Design Philosophy (1981) 

EDITA

\section{SEyTA.}

SOCIEDAD ESPAÑLAA
DE ESTETICA Y TEORIA DE LAS ARTES

CON LA COLABORACIÓN DE

\begin{tabular}{|c|c|c|}
\hline 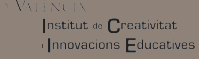 & $\begin{array}{l}\text { VNIVIRSIIA } \\
\text { In VVIIINCI Departament de Filosofia }\end{array}$ & 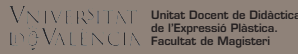 \\
\hline $\begin{array}{l}\text { TitTicA } \\
\text { SoFFA }\end{array}$ & 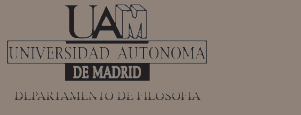 & $\begin{array}{l}\text { UAB } \\
\text { Universitat Autònoma } \\
\text { de Barcelona }\end{array}$ \\
\hline
\end{tabular}

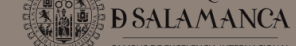

https://ojs.uv.es/index.php/LAOCOONTE/index 